7. Reprod. Fert. (1966) 12, 587-589

BRIEF COMMUNICATION

\title{
STANDARDIZATION OF PREGNANT MARE'S SERUM
}

\author{
N. K. UBEROI* AND R. K. MEYER \\ Department of Zoology, University of Wisconsin, Madison, Wisconsin
}

(Received 28th Fune 1966)

Pregnant mare's serum (PMS) is being used by various workers for inducing ovulation in the immature rat (Cole, 1936; Williams, 1945; Zarrow, Caldwell, Hafez \& Pincus, 1958; Strauss \& Meyer, 1962; McCormack \& Meyer, 1962). This report is concerned with the comparison of PMSG preparations manufactured by three different companies as regards their ability to cause ovarian growth and ovulation in the rat. Also, data relating to the effect of storage on the potency of PMSG are described.

The procedure adopted for standardization of different preparations of PMSG by ovarian weight was that of Cartland \& Nelson (1938). Twenty-oneday-old female rats were obtained from the Holtzman Company, Madison, Wisconsin and were maintained on Rockland rat and mouse diet and tap water ad libitum. They were housed in an air-conditioned room $\left(78\right.$ to $\left.80^{\circ} \mathrm{F}\right)$ providing $14 \mathrm{hr}$ of light and $10 \mathrm{hr}$ of darkness daily. The lights were turned on at 05.00 hours and off at 19.00 hours. The total dose of PMSG was divided into three equal injections given once daily at 10.00 hours starting on Day 22. The PMSG was injected subcutaneously in $1.0 \mathrm{ml}$ of $0.9 \%$ sodium chloride. Autopsy was performed on Day 26 between 10.00 hours and 14.00 hours. The ovaries were removed and weighed on a Mettler balance to the nearest $0.1 \mathrm{mg}$. Body weights were also recorded at autopsy. Estimates of potencies were calculated by standard statistical methods for parallel line assays as described by Emmens (1962).

The method adopted for standardization by ovulation is the same as reported by McCormack \& Meyer (1962) for release of ovulating hormone in PMSG treated immature rats. Twenty-one-day-old female rats were obtained from the Holtzman Company and were maintained under the same conditions as described above. On Day 22 at 07.30 hours they were injected subcutaneously with $27.5 \mathrm{i}$.u. of PMSG to be tested. PMSG was injected in $0.5 \mathrm{ml}$ of $0.9 \%$ sodium chloride. Autopsy was performed on Day 25 between 10.00 hours and 14.00 hours. The number of ova in the oviduct, ovarian weight and body weight were recorded at autopsy.

Table 1 shows the results of an assay at three dose levels of two preparations of Organon PMSG compared to Gonadogen which is a purified preparation of pregnant mare's serum gonadotrophic hormone manufactured by the Upjohn Company, Kalamazoo, Michigan. Lot No. 90648 of Organon preparation

* Postdoctoral fellow in Endocrinology-Reproductive Physiology Program. Present address: Department of Zoology, University of Delhi, Delhi, India. 
appeared to be of the same potency as Gonadogen on the basis of the ovarian method. Lot No. 14916 seemed slightly less potent. The index of precision was satisfactory. The present data confirm the conclusion of Hamburger (1957) that PMSG preparations are fairly constant in so far as their effects on ovarian and uterine weights are concerned.

TABLE 1

STANDARDIZATION OF PMGS BY OVARIAN-WEIGHT METHOD

\begin{tabular}{|c|c|c|c|}
\hline \multirow{2}{*}{$\begin{array}{c}\text { Dose of PMSG } \\
(i . u .)\end{array}$} & \multicolumn{3}{|c|}{ Ovarian weight $(m g) \pm S . E$} \\
\hline & $\begin{array}{l}\text { Upjohn LK } 263 \\
G D \text { (Gonadogen) }\end{array}$ & $\begin{array}{c}\text { Organon } \\
\text { Lot No. } 14916\end{array}$ & $\begin{array}{c}\text { Organon } \\
\text { Lot No. } 90648\end{array}$ \\
\hline $\begin{array}{c}12 \\
24 \\
48 \\
\text { Saline control }\end{array}$ & $\begin{array}{r}38 \cdot 3 \pm 1 \cdot 4 \\
64 \cdot 2 \pm 2 \cdot 7 \\
234 \cdot 7 \pm 6 \cdot 1 \\
19 \cdot 7 \pm 0.6\end{array}$ & $\begin{array}{r}34 \cdot 2 \pm 1.9 \\
51.5 \pm 3.7 \\
215.7 \pm 13.5\end{array}$ & $\begin{array}{r}35.9 \pm 1.9 \\
63.5 \pm 3.4 \\
234.4 \pm 11.5\end{array}$ \\
\hline
\end{tabular}

Ten rats/dose.

Potency of Organon Lot No. 14916 is $91 \%$

Lambda $\quad 0.05$

Potency of Organon Lot No. 90648 is $99 \%$

Lambda $\quad 0.04$

Upjohn versus No. 14916

\} Upjohn versus No. 90648

TABLE 2

STANDARDIZATION OF PMGS BY OVULATION METHOD

\begin{tabular}{|c|c|c|c|c|}
\hline $\begin{array}{l}\text { Preparation of } \\
\text { PMSG }\end{array}$ & $\begin{array}{l}\text { No. of } \\
\text { rats }\end{array}$ & $\begin{array}{l}\% \text { with } \\
\text { ova }\end{array}$ & $\begin{array}{c}\text { Average, No. of ova* } \\
\pm \text { S.E. }\end{array}$ & $\begin{array}{l}\text { Average ovarian wt. } \\
\quad(m g) \pm S . E .\end{array}$ \\
\hline $\begin{array}{l}\text { Upjohn LK263G.D. } \\
\text { (Gonadogen) }\end{array}$ & 10 & $60 \cdot 0$ & $18 \cdot 0 \pm 2 \cdot 0$ & $115 \cdot 9 \pm 6 \cdot 0$ \\
\hline $\begin{array}{l}\text { Organon } \\
\text { Lot No. } 14916\end{array}$ & 10 & $60 \cdot 0$ & $20 \cdot 5 \pm 4 \cdot 5$ & $115 \cdot 4 \pm 7 \cdot 4$ \\
\hline $\begin{array}{l}\text { Organon } \\
\text { Lot No. } 90648\end{array}$ & 10 & $80 \cdot 0$ & $22 \cdot 7 \pm 3 \cdot 9$ & $157 \cdot 0 \pm 10 \cdot 8$ \\
\hline Antex Leo & 22 & $77 \cdot 2$ & $28 \cdot 3 \pm 6 \cdot 3$ & $137 \cdot 0 \pm 11 \cdot 5$ \\
\hline $\begin{array}{l}\text { Organon } \\
\quad \text { Lot No. } 14916 \dagger\end{array}$ & 10 & $40 \cdot 0$ & $11 \cdot 7 \pm 4 \cdot 5$ & $102 \cdot 5 \pm 7 \cdot 5$ \\
\hline $\begin{array}{l}\text { Organon } \\
\text { Lot No. } 90648 \ddagger\end{array}$ & 10 & $70 \cdot 0$ & $13 \cdot 5 \pm 4 \cdot 9$ & $117 \cdot 9 \pm 9 \cdot 6$ \\
\hline Saline control & 8 & 0.0 & - & $18 \cdot 2 \pm 2 \cdot 2$ \\
\hline
\end{tabular}

* Average number of ova/ovulating rat.

$\dagger$ Frozen for 31 weeks.

$\ddagger$ Frozen for 15 weeks.

' $t$ ' test: Upjohn versus Organon Lots No. 14916 and 90648 and Antex Leo, not significant at 0.05 level. Organon 14916 versus same in frozen form, not significant at 0.05 level. Organon 90648 versus same in frozen form, not significant at 0.05 level.

The results of the experiment on the comparison of different preparations of PMSG, in so far as their ability to release ova is concerned, are shown in Table 2. The number of ova released by injecting four different preparations (Upjohn, Organon Lot No. 14196 and 90648, and Antex Leo) of PMSG was statistically the same, although the percentage of rats ovulating was slightly higher with 
Organon Lot No. 90648 and Antex Leo. The ovarian weights were less in the case of the first two preparations.

The effect of storage on the potency of the Organon preparations was determined. The lyophilized PMSG was dissolved in $0.9 \%$ of sodium chloride to a desired concentration. It was then divided into small volumes of $1.0 \mathrm{ml}$ containing 500 i.u. and frozen in vials at $-1^{\circ} \mathrm{C}$. The storage of Organon (Lot 90648) preparation in a frozen state for 15 weeks did not have much effect on ovulation, there being no statistical difference between 22.7 and 13.5 ova. The ovarian weights seemed to be affected by the storage of this preparation. Organon Lot No. 14916 stored in a frozen state for 31 weeks produced different results. The percentage of rats ovulating was lower, although there was no statistical difference in the number of ova.

This investigation was supported by a grant from the Ford Foundation.

\section{REFERENCES}

Cartland, G. F. \& Nelson, J. W. (1938) The bioassay of mare serum hormone. A comparison of ovarian and uterine weight methods. Am. F. Physiol. 122, 201.

Cole, H. H. (1936) On the biological properties of mare gonadotropic hormone. Am. F. Anat. 59, 299.

Emmens, C. W. (1962) Statistical methods. In: Methods in Hormone Research, Vol. II, p. 3. Ed. R. I. Dorfman. Academic Press, New York.

Hamburger, C. (1957) The assay of gonadotrophic hormones. A survey. Acta endocr., Copenh. Suppl. 31, 59.

MCCormack, C. E. \& MEYER, R. K. (1962) Ovulating hormone release in gonadotrophin treated immature rats. Proc. Soc. exp. Biol. Med. 110, 343.

Strauss, W. F. \& MEYer, R. K. (1962) Neural timing of ovulation in immature rats treated with gonadotrophin. Science, N.X. 137, 860.

WiLliams, P. C. (1945) Studies on the biological action of serum gonadotrophin. 3. Role of endogenous gonadotrophin. 7. Endocr. 4, 131.

Zarrow, M. X., Caldwell, A. L., Hafez, E. S. \& Pincus, G. (1958) Superovulation in the immature rat as a possible assay for LH and HCG. Endocrinology, $631,748$. 